

doi: mkts.v25i1.17945

\title{
Analisis Story Drift dan Kondisi Sendi Plastis Berbasis Performa pada Gedung Bertingkat dengan Konfigurasi Struktur Persegi Panjang, U, L, H, dan T
}

\author{
*Aji Rahmantyo, Relly Andayani \\ Program Pasca Sarjana Teknik Sipil, Universitas Gunadarma, Jakarta \\ *) aji_rahmantyo@yahoo.com
}

Received: 9 Maret 2018 Revised: 14 April 2019Accepted: 17 April 2019

\begin{abstract}
Strength based design is commonly used in the design of resisting earthquake building. It is analyzed by linear elastic method so that it can't describe the seismic behaviour of the structures. For that reason, the design of structure needs to consider performance based design. Irregularity of structure play important role for the results of Structure Performance. This paper uses five models of 20 storey reinforced concrete building with same height $(76 \mathrm{~m})$ and areas $\left(750 \mathrm{~m}^{2}\right)$ with different plan configurations: rectangular, $T, L, U$, and $H$-shaped. Non linear time history method is used to investigate the seismic behaviour of the structures, using finite model with ETABS2016. Dimension of structures are column (600 x1000 mm), shear wall (400mm), couple-beam (400x900 mm), slab (140mm). Recorded accelorogram used in this paper are Altadena, Array, Corralit, LACC, and Yermo because it has almost same earthquake mechanism, magnitude, and epicentrum distance, so that they are used as an artificial accelorogram that is synthesized using Wavelet Function according to SNI 17262012. Result shows that the story drift and plastic hinges for collapse prevention (CP) are: rectangular (story drift is $0.59 \%$ and amount of CP hinges are 8), H-shaped (1.58\%/23), L-shaped (2.41\%/30), U-shaped (4.59\%/35), $T$-shaped (5.8\%/58).
\end{abstract}

Keywords: Performanced based design, non-linear time history, strength based design, p-delta effect,story drift, plastic hinge, irregularity of structure .

\begin{abstract}
Abstrak
Desain Berbasis Kekuatan sering digunakan pada perencanaan gedung tahan gempa. Desain tersebut dianalisis dengan metode linear elastik sehingga tidak dapat menggambarkan kondisi struktur saat terjadi gempa.Oleh karena itu, struktur perlu didesain dengandesain berbasis performa. Ketidakberaturan denah struktur mempengaruhi performa struktur. Penulisan ini menggunakan lima model gedung beton bertulang 20 lantai dengan tinggi dan luasan yang sama. Tinggi bangunan adalah $76 \mathrm{~m}$ dan luas $750 \mathrm{~m}^{2}$ dengan konfigurasi denah : persegi panjang, $T, L, U$, dan $H$. Metode riwayat waktu nonlinear digunakan untuk meneliti perilaku seismik struktur dengan model elemen hingga menggunakan bantuan ETABS2016. Dimensi struktur adalah kolom (600 x1000 mm), dinding geser (400mm), balok perangkai (400x900 mm), pelat (140mm). Rekaman gempa yang digunakan adalah Altadena, Array, Corralit, LACC, dan Yermo karena rekaman gempa tersebut memiliki mekanisme gempa, skala magnitudo, dan jarak episentrum yang mendekati, sehingga kelima rekaman gempa tersebut digunakan untuk membuat rekaman gempa artifisial yang dirancang dengan fungsi Wavelet sesuai SNI 1726-2012. Hasil analisis menunjukkan bahwa nilai story drift dan kondisi sendi plastis pada collapse prevention (CP) adalah: persegi panjang (simpangan antar lantai0,59\%, jumlah sendi plastis collapse prevention 8 buah), $H(1,58 \% / 23), L(2,41 \% / 30), U(4,59 \% / 35), T(5,8 \% / 58)$.
\end{abstract}

Kata kunci: Desain berbasis performa, riwayat waktu non-linear, desain berbasis kekuatan, efek pdelta,simpangan antarlantai, sendi plastis, ketidakberaturan struktur 


\section{Pendahuluan}

Performance based design adalah suatu konsep dalam perencanaan dan analisis kegempaan struktur bangunan yang menetapkan berbagai tingkat kinerja struktur (multiple performance objective levels) (Becker, 2008).Tingkat kinerja ini adalah tingkat kinerja bangunan yang diharapkan terjadi pada saat struktur dilanda gempa dengan tingkat intensitas tertentu (Housner, 1956).Tingkat kinerja (performance) ini merupakan suatu pilihan yang harus ditentukan oleh perencanaan struktur pada tahap awal, dimana tingkat kinerja ini dapat dievaluasi dari beberapa kondisi batas.

Kondisi batas ini ditentukan menurut ATC-40 berdasarkan kondisiimmediate occupancy (IO), life safety (LS), dan collapse prevention (CP).Banyaknya terjadi kasus keruntuhan bangunan di Indonesia yang mengacu kepada kode SNI dan peraturan gempa menimbulkan perkembangan peraturan pembebanan terhadap gempa yang menuju ke performance based design. (Sukamta, 2016).

Terdapat dua jenis analisis yang saat ini umum digunakan dalam performance-based seismic design (PBSD), yaitu nonlinear response history analysis (NLHRA) dan nonlinear static procedure(NSP).NSP merupakan jenis analisis nonlinear yang paling praktis dilakukan namun dinilai kurang akurat karena keterbatasannya mencakup pengaruh ragam getar tinggi. Modal pushover analysis (MPA) merupakan prosedur alternatif untuk pengembangan analisis NSP (Chopra\& Goel,2001), sedangkan adaptive modal combination (AMC) merupakan pengembangan dari metode MPA (Kalkan \& Kunnath,2006) namun metode tersebut tidak cocok untuk digunakan pada gedung yang memiliki ketidakberaturan bentuk ataupun setback, sehingga, NLRHA dinilai paling ideal dan akurat untuk analisis gedung tinggi.

Penelitian terdahulu yang telah membahas tentang analisis pengaruh denah struktur terhadap kinerja performa struktur antara lain adalah ketidakberaturan struktur dengan konfigurasi denah yang berbeda menggunakan metode respon spektrum linier (Guleria,2014), dan perbandingan Analisis dinamis respon spektrum linear pada gedung T dan Gedung L (Agrahari et al., 2017).

Peneliti yang telah membahas tentang performa struktur dengan metode non linear time history analysis adalah analisis non linear gedung bertingkat tinggi (Khan et al., 2014), respon nonlinear pada gedung Masonry (Zheng et al., (2012), analisis non linear time history pada gedung tinggi dengan setback (Lu et al., 2011), analisis non linear time history pada gedung Masonry (Betti et al., 2015), energi gempa dengan analisis non linear time history (Manfredi, 2001), energi input dan disipasi struktur dengan redaman histeretik (Nakashima et al, 1996), pendekatan energi input gempa menggunakan metode non linear time history (Uang \& Bertero, 1990), energi gempa yang diserap struktur SDOF (Zahrah \& Hall,1984), performa seismik gedung SRPMK dan dinding geser dengan non linear time history (Seo,2015), dan analisis non linear time history pada tingkat intensitas gempa yang berbeda (Juni et al., 2017).

Penelitian terdahulu belum membahas tentang analisis pengaruh denah struktur terhadap kinerja peforma struktur berdasarkan performance based design dengan metode non linear time history analysis, sehingga pada penelitian ini akan membahas tentang pengaruh denah struktur terhadap kinerja performa struktur.

\section{Metode}

\section{Informasi umum}

Pada penulisan ini, digunakan lima buah model gedung rencana dengan konfigurasi bentuk yang berbeda, namun dengan jumlah lantai, luasan, dan ketinggian yang sama yaitu 20 lantai, dengan ketinggian $76,56 \mathrm{~m}(20 \mathrm{ft})$, luasan lantai $\pm 750 \mathrm{~m}^{2}$ menggunakansistem ganda, sesuai dengan peraturan SNI 1726-2012, SNI 2847-2013, dan SNI 1727-2013. Bentuk model bangunan yang direncanakan adalah bentuk persegi panjang, bentuk T, bentuk $\mathrm{H}$, bentuk $\mathrm{L}$, dan bentuk $\mathrm{U}$.

Dimensi struktur yang digunakan adalah sama, yaitu balok perangkai dimensi $(400 \times 900) \mathrm{mm}$. Tebal Pelat 140 vmm. Tebal dinding geser $400 \mathrm{~mm}$. Dimensi Kolom (600x1000) mm. Pemodelan struktur dibuat dengan menggunakan software ETABS. Gambar denah struktur dapat dilihat pada Gambar 1.

\section{Pembebanan gempa}

Pembebanan gempa pada perancangan bangunan ini menggunakan analisis respon spektra pada daerah Jakarta. Beban gempa respons spektrum Jakarta akan digunakan sebagai acuan untuk analisis non linear time history. Bangunan terletak pada tanah sedang.

Berdasarkan SNI 1726-2012, pembebanan gempa untuk bangunan sistem ganda yang terletak di Jakarta memiliki parameter seperti pada Tabel 1. 


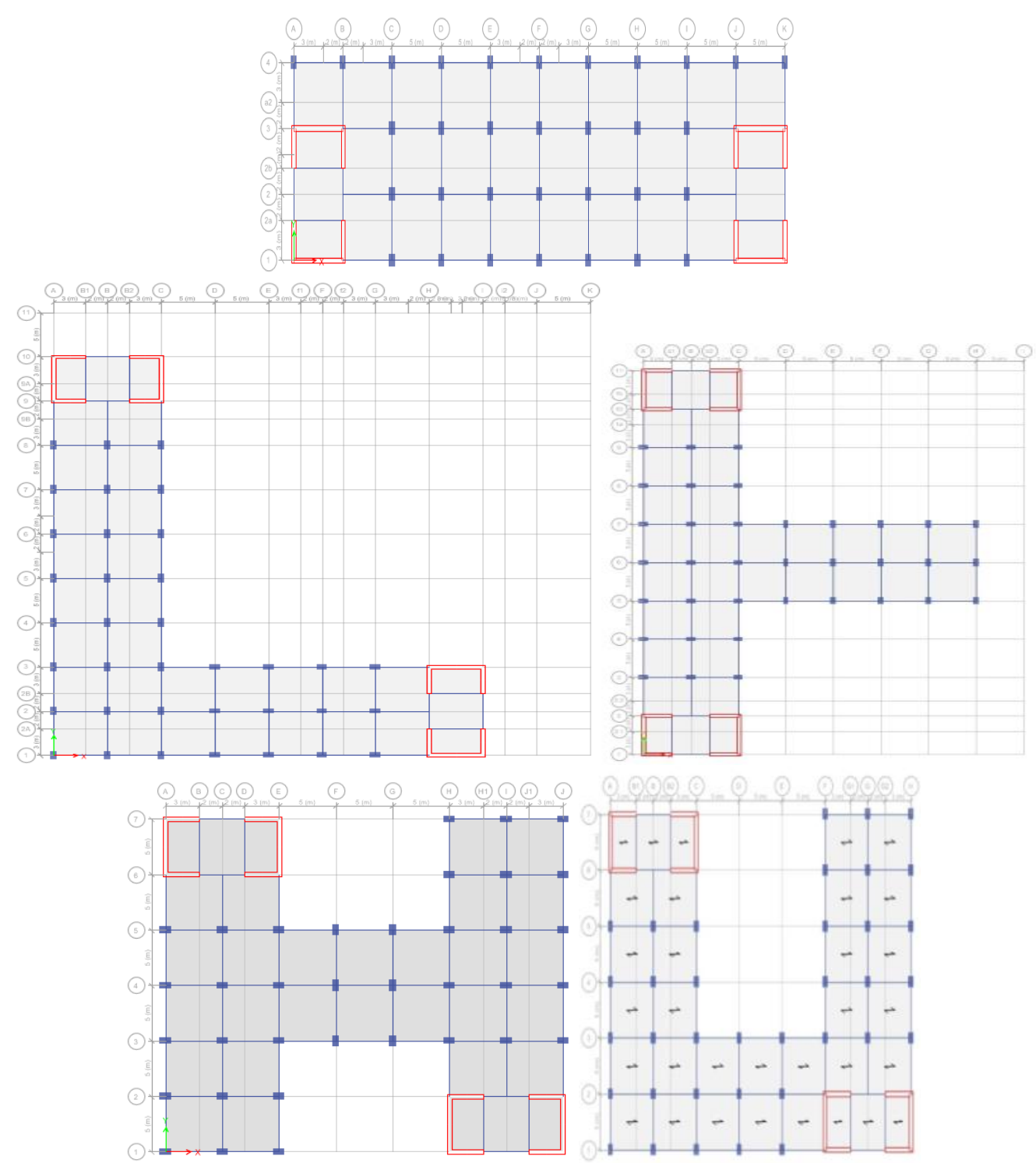

Gambar 1. Denah struktur bentuk persegi, T, L, H,dan U

\section{Hasil Pembahasan}

\section{Analisis rasio partisipasi massa}

Berdasarkan SNI 1726-2012, mode-1 dan mode-2 harus berada dalam kondisi dominan translasi sedangkan mode ke-3 dan seterusnya dibolehkan untuk dominan rotasi. Berdasarkan Tabel 2, dapat disimpulkan bahwa lima denah tersebut telah memenuhi persyaratan ragam mode bangunan. Pada bangunan Bentuk L, mode-1 dan mode-2 bangunan tidak dominan translasi satu arah, namun secara umum bangunan masih dominan Translasi sehingga bangunan bentuk L dapat digunakan untuk analisis performa.

\section{Kontrol defleksi akibat beban gempa}

Berdasarkan SNI 1726-2012, syarat simpangan antar lantai tingkat desain $(\Delta)$ pada tipe bangunan kategori resiko I dan II untuk seluruh struktur lain adalah sebesar $2 \%$ dari tingkat bangunan.

Tabel 1. Parameter respons spektrum

\begin{tabular}{cc}
\hline Parameter & Nilai \\
\hline Ie & II \\
Faktor keutamaan & 1 \\
Klasifikasi situs & SD tanah sedang \\
$\mathrm{Ss}$ & 0,69 \\
$\mathrm{~S}_{1}$ & 0,3 \\
$\mathrm{~F}_{\mathrm{a}}$ & 1,25 \\
$\mathrm{~F}_{\mathrm{v}}$ & 1,8 \\
$\mathrm{~S}_{\mathrm{ms}}$ & 0,86 \\
$\mathrm{~S}_{\mathrm{m} 1}$ & 0,54 \\
$\mathrm{~S}_{\mathrm{ds}}$ & 0,57 \\
$\mathrm{~S}_{\mathrm{d} 1}$ & 0,36 \\
$\mathrm{R}$ & 7 \\
Omega $(\Omega)$ & 2,5 \\
$\mathrm{Cd}$ & 5,5 \\
\hline
\end{tabular}


Simpangan antar lantai tiap denah dapat dilihat pada gambar 2. Defleksi pusat massa di tiap tingkat ditentukan dengan menggunakan Persamaan 1.

$$
\delta x=\frac{C d . \delta x e}{I e}
$$

Dimana $\mathrm{Cd}$ merupakan faktor amplikasi defleksi, dan $\delta$ xe adalah defleksi pada tingkat yang ditinjau, sedangkan Ie adalah faktor keutamaan gempa. Rekapitulasi nilai simpangan antar lantai untuk setiap denah dapat dilihat pada Gambar 2.

\section{Kontrol kinerja terhadap pengaruh P-Delta}

P-Delta merupakan efek sekunder yang bekerja pada elemen struktur, yang diakibatkan oleh penambahan beban vertikal sebagai akibat dari perpindahan horizontal struktur. Pengaruh P-Delta, tidak disyaratkan untuk diperhitungkan apabila koefisien stabilitas $(\theta)$ kurang atau sama dengan 0,1 . Koefisien stabilitas diperhitungkan dengan rumus(Persamaan 2)

$\theta=\frac{P \cdot \Delta \cdot I e}{V \cdot h_{S x} \cdot C_{d}}$

Koefisien stabilitas harus tidak melebihi $\theta_{\max }$ yang ditentukan dengan Persamaan 3.

$\theta_{\max }=\frac{0,5}{\beta . C d}$

SNI 1726-2012 mengijinkan rasio $\beta$ secara konservatif diambil sebesar 1,0. Berdasarkan rumusan tersebut, nilai $\theta_{\max }$ adalah 0,09 . Berdasarkan hasil analisis dari lima tipe gedung, didapatkan nilai $\theta$ lebih kecil dari $\theta_{\max }$ sehingga kondisi gedung stabil terhadap efek P-Delta. Rekapitulasi nilai P-Delta untuk setiap denah dapat dilihat pada Tabel 3 .

Tabel 2. Partisipasi massa rasio 5 denah

\begin{tabular}{lcccccc}
\hline \multicolumn{1}{c}{ Tipe denah } & Mode & Periode (detik) & $\mathbf{U x}$ & $\mathbf{U y}$ & $\mathbf{R z}$ & Keterangan \\
\hline \multirow{2}{*}{ Persegi } & 1 & 1,97 & 0,998 & 0,000 & 0,002 & Translasi X \\
panjang & 2 & 1,86 & 0,000 & 1,000 & 0,000 & Translasi Y \\
& 3 & 1,33 & 0,002 & 0,000 & 0,998 & Rotasi Z \\
\hline \multirow{3}{*}{ Bentuk T } & 1 & 2,07 & 0,000 & 0,969 & 0,031 & Translasi Y \\
& 2 & 1,92 & 1,000 & 0,000 & 0,000 & Translasi X \\
& 3 & 1,40 & 0,000 & 0,032 & 0,968 & Rotasi Z \\
\hline \multirow{3}{*}{ Bentuk L } & 1 & 2,02 & 0,74 & 0,195 & 0,065 & Translasi X \\
& 2 & 1,94 & 0,225 & 0,769 & 0,006 & Translasi Y \\
Bentuk H & 3 & 1,37 & 0,035 & 0,036 & 0,929 & Rotasi Z \\
& 1 & 1,85 & 0,002 & 0,998 & 0,000 & Translasi Y \\
& 3 & 1,74 & 0,998 & 0,002 & 0,000 & Translasi X \\
Bentuk U & 1 & 1,43 & 0,000 & 0,000 & 1,000 & Rotasi Z \\
& 2 & 1,97 & 0,002 & 0,998 & 0,000 & Translasi Y \\
& 3 & 1,91 & 0,997 & 0,002 & 0,001 & Translasi X \\
\hline
\end{tabular}

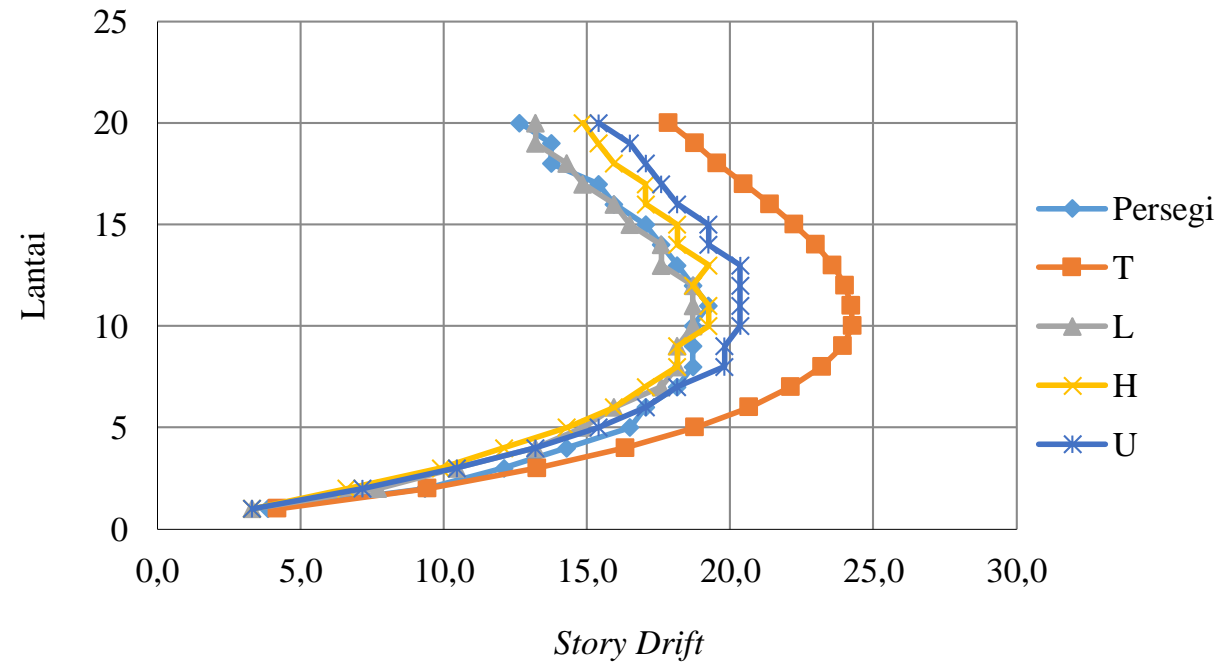

Gambar 2. Simpangan antar lantai 
Tabel 3. Nilai P- Delta

\begin{tabular}{|c|c|c|c|c|c|c|c|c|c|c|c|c|}
\hline \multirow{3}{*}{ Lantai } & \multicolumn{10}{|c|}{ Denah struktur } & \multirow[t]{3}{*}{$\theta \max$} & \multirow[t]{3}{*}{ Status } \\
\hline & \multicolumn{2}{|c|}{ Persegi } & \multicolumn{2}{|c|}{$\mathbf{T}$} & \multicolumn{2}{|c|}{$\mathbf{L}$} & \multicolumn{2}{|c|}{ H } & \multicolumn{2}{|c|}{$\mathbf{U}$} & & \\
\hline & $\theta \mathbf{x}$ & $\theta y$ & $\theta \mathbf{x}$ & $\theta \mathbf{y}$ & $\theta \mathbf{x}$ & $\theta \mathbf{y}$ & $\theta \mathbf{x}$ & $\theta \mathbf{y}$ & $\theta \mathbf{x}$ & $\theta y$ & & \\
\hline 20 & 0,013 & 0,011 & 0,012 & 0,017 & 0,013 & 0,012 & 0,011 & 0,016 & 0,012 & 0,014 & 0,091 & Stabil \\
\hline 19 & 0,013 & 0,012 & 0,013 & 0,017 & 0,007 & 0,006 & 0,011 & 0,016 & 0,012 & 0,015 & 0,091 & Stabil \\
\hline 18 & 0,015 & 0,012 & 0,014 & 0,018 & 0,014 & 0,013 & 0,013 & 0,017 & 0,013 & 0,016 & 0,091 & Stabil \\
\hline 17 & 0,012 & 0,011 & 0,009 & 0,012 & 0,015 & 0,014 & 0,014 & 0,018 & 0,015 & 0,017 & 0,091 & Stabil \\
\hline 16 & 0,017 & 0,015 & 0,016 & 0,022 & 0,017 & 0,016 & 0,015 & 0,019 & 0,012 & 0,013 & 0,091 & Stabil \\
\hline 15 & 0,018 & 0,017 & 0,018 & 0,024 & 0,007 & 0,006 & 0,016 & 0,021 & 0,017 & 0,02 & 0,091 & Stabil \\
\hline 14 & 0,02 & 0,018 & 0,019 & 0,025 & 0,019 & 0,019 & 0,018 & 0,022 & 0,019 & 0,021 & 0,091 & Stabil \\
\hline 13 & 0,022 & 0,02 & 0,021 & 0,027 & 0,022 & 0,02 & 0,019 & 0,024 & 0,02 & 0,023 & 0,091 & Stabil \\
\hline 12 & 0,023 & 0,021 & 0,022 & 0,029 & 0,023 & 0,022 & 0,021 & 0,025 & 0,022 & 0,024 & 0,091 & Stabil \\
\hline 11 & 0,024 & 0,023 & 0,024 & 0,031 & 0,024 & 0,023 & 0,022 & 0,027 & 0,023 & 0,025 & 0,091 & Stabil \\
\hline 10 & 0,025 & 0,023 & 0,025 & 0,033 & 0,017 & 0,016 & 0,023 & 0,028 & 0,024 & 0,027 & 0,091 & Stabil \\
\hline 9 & 0,027 & 0,024 & 0,026 & 0,034 & 0,017 & 0,016 & 0,024 & 0,028 & 0,023 & 0,025 & 0,091 & Stabil \\
\hline 8 & 0,026 & 0,026 & 0,017 & 0,022 & 0,027 & 0,026 & 0,025 & 0,029 & 0,026 & 0,029 & 0,091 & Stabil \\
\hline 7 & 0,027 & 0,026 & 0,028 & 0,035 & 0,027 & 0,026 & 0,025 & 0,029 & 0,027 & 0,028 & 0,091 & Stabil \\
\hline 6 & 0,028 & 0,028 & 0,028 & 0,034 & 0,027 & 0,025 & 0,026 & 0,028 & 0,027 & 0,027 & 0,091 & Stabil \\
\hline 5 & 0,024 & 0,027 & 0,028 & 0,033 & 0,026 & 0,025 & 0,025 & 0,027 & 0,019 & 0,019 & 0,091 & Stabil \\
\hline 4 & 0,025 & 0,027 & 0,026 & 0,03 & 0,023 & 0,023 & 0,023 & 0,024 & 0,024 & 0,024 & 0,091 & Stabil \\
\hline 3 & 0,021 & 0,024 & 0,023 & 0,026 & 0,02 & 0,019 & 0,021 & 0,02 & 0,022 & 0,02 & 0,091 & Stabil \\
\hline 2 & 0,011 & 0,013 & 0,018 & 0,019 & 0,016 & 0,015 & 0,017 & 0,014 & 0,017 & 0,014 & 0,091 & Stabil \\
\hline 1 & 0,006 & 0,006 & 0,008 & 0,009 & 0,007 & 0,007 & 0,007 & 0,008 & 0,008 & 0,007 & 0,091 & Stabil \\
\hline
\end{tabular}

Tabel 4. Data rekaman gempa

\begin{tabular}{lccc}
\hline \multicolumn{1}{c}{ Gempa } & Magnitudo & PGA & $\begin{array}{c}\text { Jarak epicenter } \\
(\mathbf{k m})\end{array}$ \\
\hline Altadena,Eaton Canyon Park, Sierra Made Earthquake, 1991 & $5,60 \mathrm{SR}$ & $0,44 \mathrm{~g}$ & 17,4 \\
Array 6, El Centro, Imperial Valley Earthquake, 1979 & $6,53 \mathrm{SR}$ & $0,28 \mathrm{~g}$ & 13,2 \\
Corralit, Eureka Canyon RD, Morgan Hill Earthquake, 1984 & $6,20 \mathrm{SR}$ & $0,12 \mathrm{~g}$ & 32,0 \\
Lacc, Century City, Northridge Earthquake, 1994 & $6,70 \mathrm{SR}$ & $0,26 \mathrm{~g}$ & 20,0 \\
Yermo - Fire Stasion, Landers Earthquake, 1992 & $7,30 \mathrm{SR}$ & $0,23 \mathrm{~g}$ & 31,0 \\
\hline
\end{tabular}

\section{Analisis nonllinear time history}

Analisis beban gempa nonlinear diperhitungkan dengan menggunakan lima rekaman gempa riwayat waktu.Berdasarkan pasal 11.1.3 SNI 1726-2012, jumlah rekaman gempa yang digunakan untuk analisis non linear time history diambil paling sedikit tiga rekaman gempa. Rekaman gempa yang sesuai diseleksi dari peristiwa-peristiwa gempa yang memiliki magnitudo, jarak patahan, dan mekanisme sumber gempa yang konsisten dengan hal-hal yang mengontrol ketentuan gempa maksimum yang dipertimbangkan. Apabila jumlah rekaman gempa dianggap tidak mencukupi, maka harus digunakan rekaman gempa buatan.

Rekaman gempa skala asli bersumber dari situs PEER Berkeley yang merupakan rekaman gempa dengan percepatan gempa pada permukaan (ground motion accelaration). Mekanisme peristiwa rekaman gempa asli dan data rekaman gempa dapat dilihat pada Tabel 4.Analisis rekaman gempa buatan diskalakan berdasarkan MCEr gempa SNI
1726-2012. Rekaman gempa buatan harus diskalakan sedemikian rupa sehingga pada rentang periode dari 0,2 hingga $1,5 \mathrm{~T}$, nilai rata-rata spektrum dari komponen horizontal tidak boleh kurang dari nilai ordinat terkait pada spektrum respon yang digunakan dalam desain, dimana nilai $\mathrm{T}$ adalah nilai periode getar alami struktur. Perbandingan untuk rekaman gempa permukaan (ground motion acceleration) dan percepatan batuan dasar (bedrock) dapat dilihat pada Gambar 3. Parameter yang ditinjau dari adalah jumlah sendi plastis yang terjadi pada tiap denah gedung, kondisi story drift pada tiap denah gedung, perbandingan nilai rotasi sendi plastis serta momen sendi plastis pada 10 lantai pertama dari lima denah gedung yang berbeda, serta nilai momen kolom maksimum dari 10 lantai pertama pada lima denah gedung.Rekaman gempa sintesis buatan berdasarkan respon spektrum SNI 1726-2012 dihitung berdasarkan metode domain waktu (time domain) dengan fungsi Wavelet menggunakan bantuan program ETABS 2016 berdasarkan algoritma Lilihanand \& Tseng, (1988). 


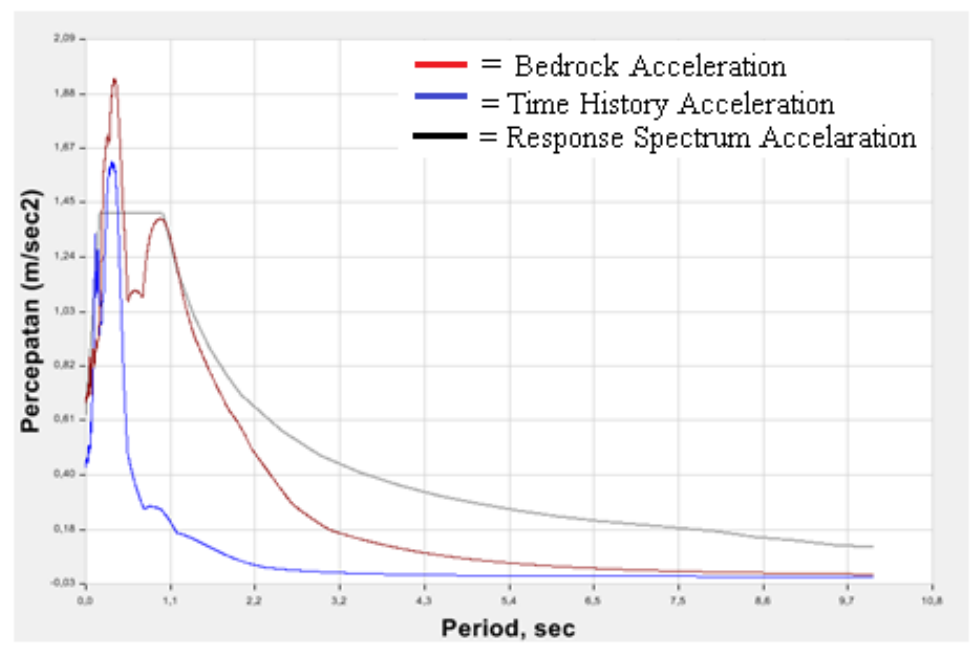

Gambar 3. Percepatan batuan dasar dan percepatan permukaan gempa
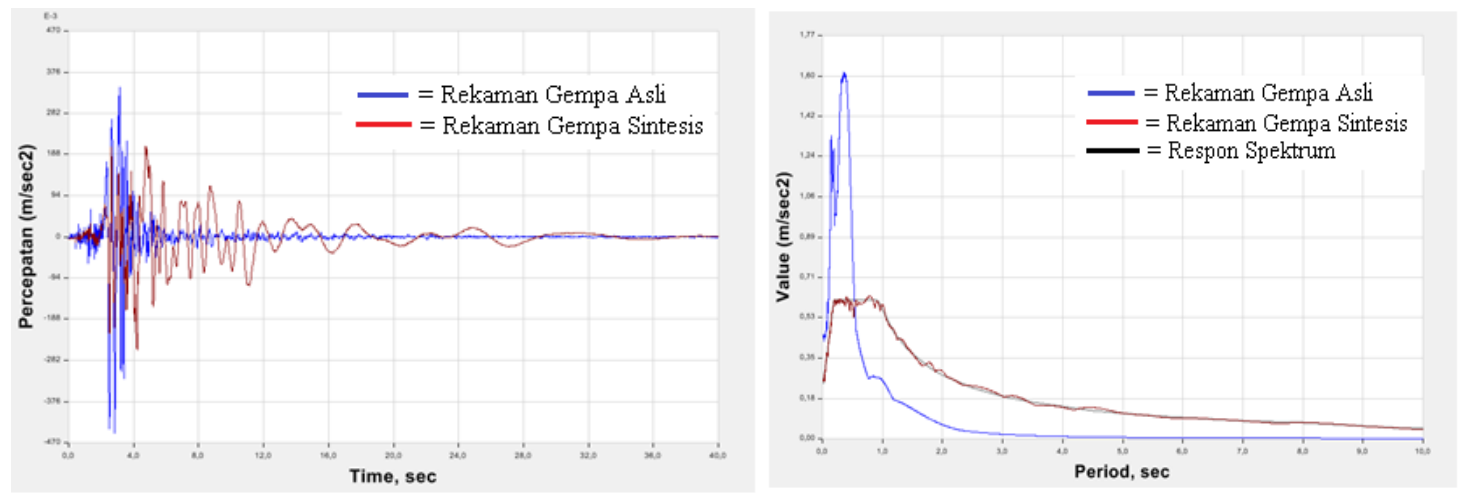

Gambar 4. Sintesis rekaman gempa

Waktu getar struktur pada lima denah berkisar antara 1,3 detik dan 2,1 detik, sehingga, berdasarkan SNI 1726-2012 pasal 11, nilai ordinat pada rekaman gempa yang disintesis tidak boleh lebih kecil dari respon spektrum dalam rentang periode $0,2-1,5 \mathrm{~T}$,yang berarti antara $2,6-3,15$ detik. Berdasarkan hasil sintesis gempa buatan pada Gambar 4, diperoleh nilai ordinat pada periode 2,6 - 3,15 detik lebih besar dari respon spektrum, sehingga rekaman gempa tersebut dapat digunakan untuk analisis non linear riwayat waktu.

\section{Kondisi sendi plastis}

Kondisi sendi plastis ditinjau pada dua tahap.Tahapan pertama dimulai dari peristiwa terjadinya keruntuhan pada struktur akibat rekaman gempa asli. Analisis pada tahap pertama akan menunjukkan mekanisme keruntuhan bangunan dan jumlah sendi plastis yang terjadi pada tiap elemen struktur.Tahapan kedua menunjukkan kondisi sendi plastis pada seluruh elemen struktur saat dibebani rekaman gempa sintesis. Kondisi sendi plastis yang ditinjau terbagi atas sendi plastis pada balok dan sendi plastis pada dinding geser. Berdasarkan kondisi sendi plastis, dapat dilihat bahwa pemodelan gedung bentuk persegi memiliki performa yang baik karena mengalami kondisi sendi plastis collapse prevention yang paling sedikit dibandingkan dengan gedung bentuk lain.

Gedung bentuk $\mathrm{T}$ merupakan gedung dengan performa yang paling buruk karena mengalami kondisi sendi plastis collapse prevention yang berbanyak dibandingkan dengan denah bangunan lain. Kondisi sendi plastis dapat dilihat pada Tabel 5 sampai dengan 9. Berdasarkan performa sendi plastis dari lima rekaman gempa asli, dapat disimpulkan bahwa gedung denah persegi merupakan denah yang memiliki performa terbaik. Hal ini dapat ditunjukkan dengan kondisi sendi plastis yang memiliki jumlah sendi dalam kondisi LS-CP yang terkecil. Kondisi sendi plastis LS-CP pada elemen dinding geser denah persegi lebih kecil dibandingkan dengan denah lain. Meskipun kondisi LS-CP pada elemen balok lebih besar dibandingkan dengan denah lain, namun dinding geser merupakan elemen utama yang menahan beban gempa, sehingga gedung persegi yang memiliki kondisi plastis LS-CP terkecil pada dinding geser merupakan gedung dengan performa terbaik berdasarkan kondisi sendi plastis. 
Tabel 5. Kondisi sendi plastis Gempa Altadena

\begin{tabular}{ccccccccccccc}
\hline \multirow{2}{*}{ Tahap } & & \multicolumn{2}{c}{ Persegi } & \multicolumn{2}{c}{ T } & \multicolumn{2}{c}{ L } & \multicolumn{2}{c}{ H } & \multicolumn{2}{c}{ U } \\
\cline { 2 - 12 } & Sendi & Beam & Wall & Beam & Wall & Beam & Wall & Beam & Wall & Beam & Wall \\
\hline \multirow{2}{*}{1} & A-IO & 2.822 & 211 & 2.826 & 218 & 2.839 & 203 & 2.840 & 204 & 2.835 & 207 \\
& IO-LS & & 20 & 14 & 12 & 1 & 26 & & 26 & 5 & 23 \\
2 & LS-CP & 18 & 9 & & 11 & & 10 & & 10 & & 10 \\
2 & A-IO & 2840 & 240 & 2.840 & 240 & 2.840 & 240 & 2.840 & 240 & 2.840 & 240 \\
\hline
\end{tabular}

Tabel 6. Kondisi sendi plastis Gempa Array

\begin{tabular}{cccccccccccc}
\hline \multirow{2}{*}{ Tahap } & & \multicolumn{2}{c}{ Persegi } & \multicolumn{2}{c}{ T } & \multicolumn{2}{c}{ L } & \multicolumn{2}{c}{ H } & \multicolumn{2}{c}{ U } \\
\cline { 3 - 11 } & Sendi & Beam & Wall & Beam & Wall & Beam & Wall & Beam & Wall & Beam & Wall \\
\hline \multirow{2}{*}{1} & A-IO & 2.822 & 201 & 2.840 & 184 & 2.839 & 192 & 2.840 & 207 & 2.832 & 201 \\
& IO-LS & 9 & 29 & & 44 & 1 & 33 & & 21 & & 24 \\
2 & LS-CP & 9 & 10 & & 15 & & 15 & & 12 & 8 & 15 \\
2 & A-IO & 2.840 & 240 & 2.840 & 240 & 2.840 & 240 & 2.840 & 240 & 2.840 & 240 \\
\hline
\end{tabular}

Tabel 7. Kondisi sendi plastis Gempa Corralit

\begin{tabular}{cccccccccccc}
\hline \multirow{2}{*}{ Tahap } & & \multicolumn{2}{c}{ Persegi } & \multicolumn{2}{c}{ T } & \multicolumn{2}{c}{ L } & \multicolumn{2}{c}{ H } & \multicolumn{2}{c}{ U } \\
\cline { 3 - 11 } & Sendi & Beam & Wall & Beam & Wall & Beam & Wall & Beam & Wall & Beam & Wall \\
\hline \multirow{2}{*}{1} & A-IO & 2.819 & 188 & 2.803 & 170 & 2.838 & 186 & 2.840 & 165 & 2.833 & 181 \\
& IO-LS & 6 & 37 & 37 & 40 & 2 & 39 & & 50 & 7 & 39 \\
2 & LS-CP & 15 & 15 & & 30 & & 25 & & 25 & 26 \\
2 & A-IO & 2.840 & 240 & 2.840 & 240 & 2.840 & 240 & 2.840 & 240 & 2.840 & 240 \\
\hline
\end{tabular}

Tabel 8. Kondisi sendi plastis Gempa LACC

\begin{tabular}{ccccccccccccc}
\hline \multirow{2}{*}{ Tahap } & & \multicolumn{2}{c}{ Persegi } & \multicolumn{2}{c}{ T } & \multicolumn{2}{c}{ L } & \multicolumn{2}{c}{ H } \\
\cline { 3 - 11 } & Sendi & Beam & Wall & Beam & Wall & Beam & Wall & Beam & Wall & Beam & Wall \\
\hline \multirow{2}{*}{1} & A-IO & 2822 & 153 & 2774 & 132 & 2838 & 142 & 2840 & 164 & 2832 & 147 \\
& IO-LS & & 71 & 66 & 42 & 1 & 65 & & 59 & 6 & 70 \\
2 & LS-CP & 18 & 16 & & 66 & 1 & 33 & & 17 & 2 & 34 \\
& A-IO & 2840 & 240 & 2840 & 240 & 2840 & 240 & 2840 & 240 & 2840 & 240 \\
\hline
\end{tabular}

Tabel 9. Kondisi sendi plastis Gempa Yermo

\begin{tabular}{|c|c|c|c|c|c|c|c|c|c|c|c|}
\hline \multirow{2}{*}{ Tahap } & \multirow[b]{2}{*}{ Sendi } & \multicolumn{2}{|c|}{ Persegi } & \multicolumn{2}{|c|}{$\mathbf{T}$} & \multicolumn{2}{|c|}{$\mathbf{L}$} & \multicolumn{2}{|c|}{ H } & \multicolumn{2}{|c|}{$\mathbf{U}$} \\
\hline & & beam & wall & beam & wall & Beam & Wall & beam & wall & beam & wall \\
\hline & A-IO & 2.821 & 212 & 2.830 & 132 & 2.838 & 177 & 2.840 & 165 & 2.832 & 162 \\
\hline 1 & IO-LS & 6 & 20 & 10 & 50 & 1 & 40 & & 45 & & 43 \\
\hline & LS-CP & 13 & 8 & & 58 & 1 & 30 & & 23 & 8 & 35 \\
\hline 2 & A-IO & 2.840 & 240 & 2.840 & 240 & 2.840 & 240 & 2.840 & 240 & 2.840 & 240 \\
\hline
\end{tabular}

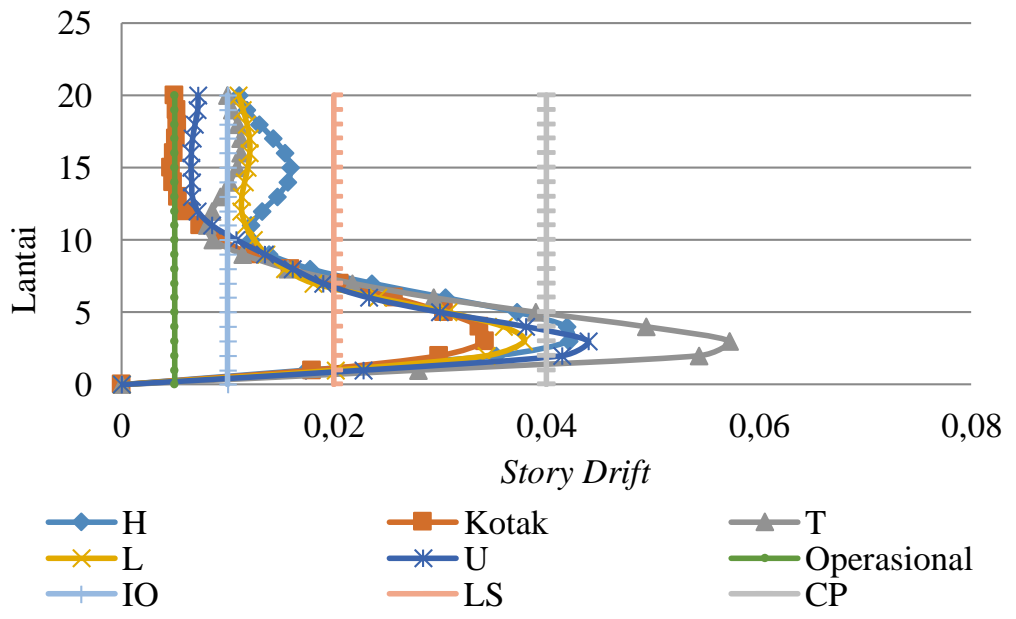

a. Story drift Gempa Altadena 


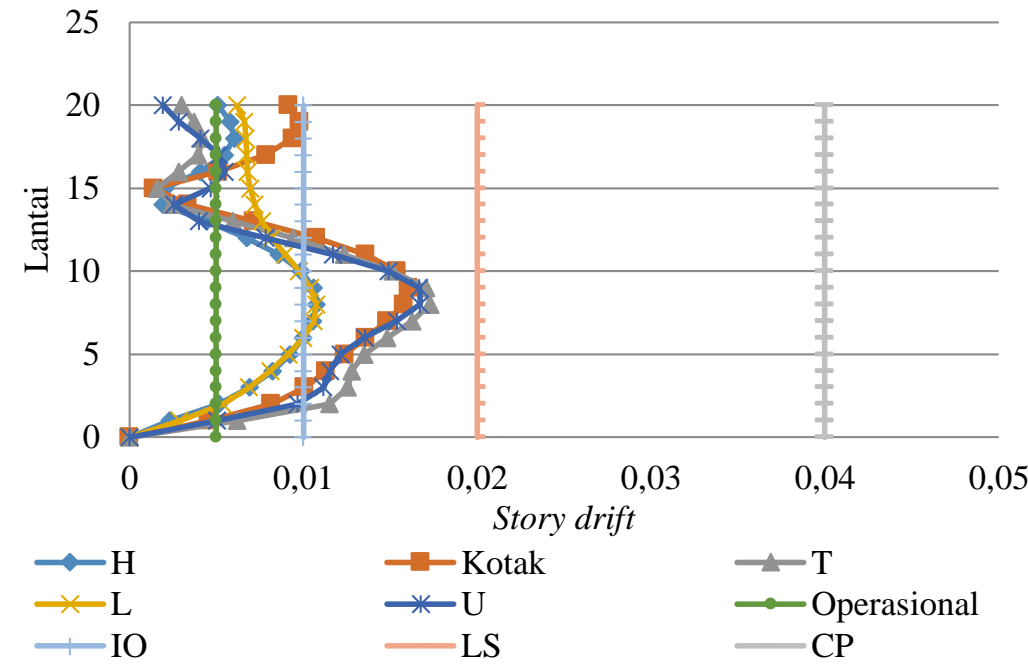

b. Story driftGempa Array

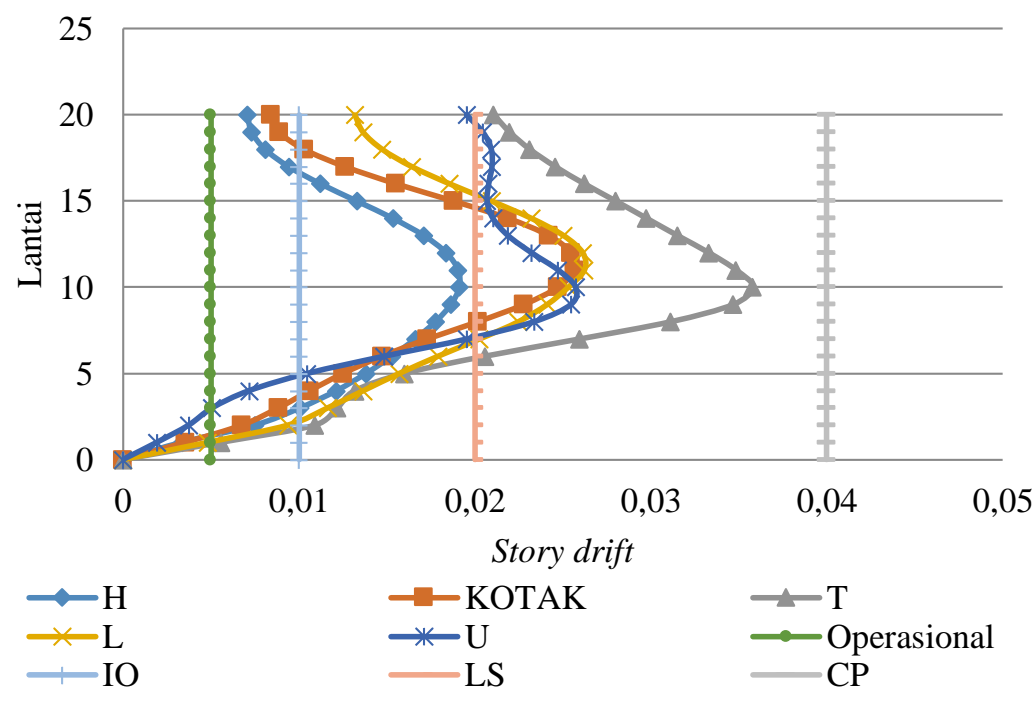

c. Story drift Gempa Corralit

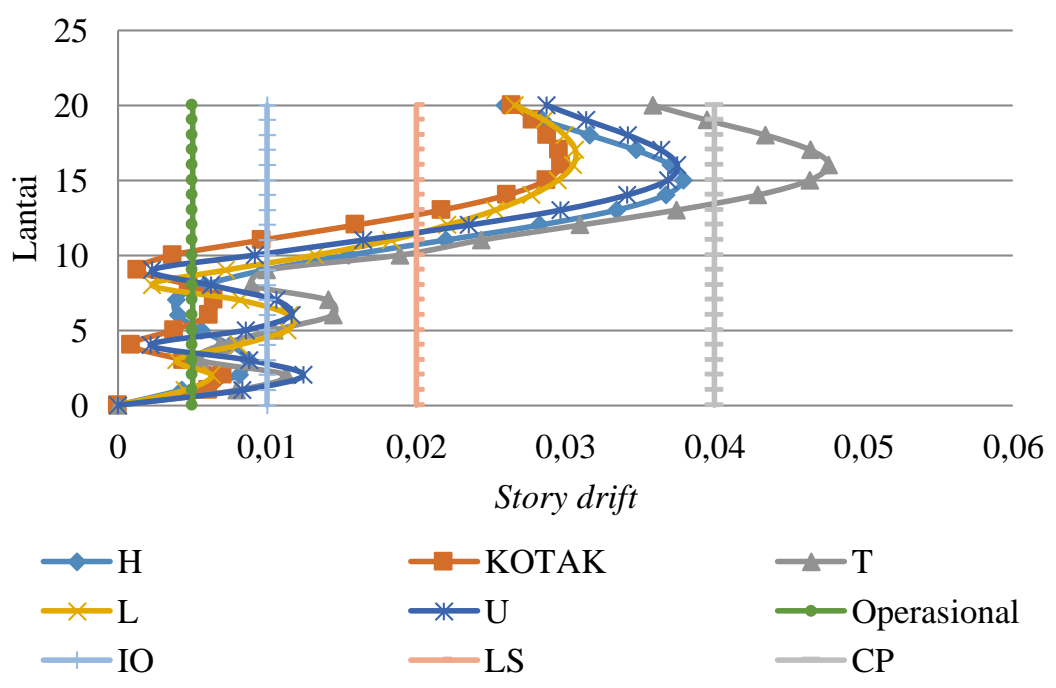

d. Story drift Gempa LACC 




e. Story drift Gempa Yermo

Gambar 5.. Nilai Story Drift

Performa gedung mulai dari yang terbaik hingga terburuk adalah persegi, H, L, U dan T. Gedung T merupakan gedung dengan performa terburuk karena pada denah $\mathrm{T}$, terbentuk sendi plastis dalam kondisi LS-CP pada dinding geser dengan jumlah yang terbanyak. Selain parameter sendi plastis, penilaian performa bangunan yang akan ditinjau pada tiap denah adalah story drift. Nilai story drift dapat dilihat pada Gambar 5.

Berdasarkan Pengecekan story drift dari lima gempa, dapat disimpulkan bahwa secara menyeluruh, bangunan dengan denah persegi panjang memiliki story drift yang lebih kecil dibandingkan dengan denah struktur lainnya, sedangkan gedung $\mathrm{T}$ memiliki story drift terbesar dibandingkan dengan denah lainnya dengan demikian dapat disimpulkan bahwa gedung persegi panjang memiliki performa lebih baik dibandingkan dengan denah struktur lain. Performa struktur dari mulai yang terbaik sampai terburuk adalah persegi panjang, H, L, U, dan T.

\section{Kesimpulan}

Dari hasil pembahasan, dapat disimpulkan berdasarkan performa sendi plastis dan story drift pada kasus rekaman gempa asli, gedung denah persegi merupakan denah dengan performa terbaik. Kinerja performa dari terbaik sampai terburuk adalah denah persegi panjang, H, L, U, dan T.

Berdasarkan performa story drift pada kasus rekaman gempa asli, gedung denah persegi merupakan denah dengan performa terbaik. Nilai story drift adalah:persegi panjang (0,59\%), $\mathrm{H}$ (1,58\%), L (2,41\%), U (4,59\%), T (5,8\%). Berdasarkan performa rotasi sendi plastis pada kasus rekaman gempa asli, gedung denah persegi merupakan denah dengan performa terbaik. Nilai kondisi sendi plastis pada kondisi CP (Collapse Prevention) adalah: persegi panjang (8), H (23), L (30), U (35), T (58).

\section{Ucapan Terima Kasih}

Penulis mengucapkan terima kasih sebesarbesarnya kepada Program Pasca Sarjana Teknik Sipil Universitas Gunadarma selaku pemberi dana penelitian dan donatur serta Dr. Relly Andayani selaku dosen pembimbing penulisan karya ilmiah.

\section{Daftar Pustaka}

Agrahari, A., Pawar, S., \&Pujari, A.(2017). Dynamic Analysis and Comparison of Multi Storey L-Shaped and T-Shaped Building.International Journal of Innovative Research in Science, Engineering, and Technology, 6(5), 9511-9517.

ATC 40. (1996). Seismic Evaluation and Retrofit of Concrete Buildings. California: Seismic State Commision of California.

Badan Standarisasi Nasional. (2012). SNI 17262012 Tata cara perencanaan ketahanan gempa untuk struktur bangunan gedung dan non gedung. Jakarta : Badan Standarisasi Nasional.

Badan Standarisasi Nasional. (2013). SNI 28472013 Persyaratan beton struktural untuk bangunan gedung. Jakarta: Badan Standarisasi Nasional.

Badan Standarisasi Nasional. (2013). SNI $1727-$ 2013. Beban minimum untuk perancangan bangunan gedung dan struktur lain. Jakarta: Badan Standarisasi Nasional. 
Becker, R.(2008).Fundamentals of PerformanceBased Building Design.Building Simulation, 1(4), 356-371.

Betti, M., Galano, L.,\&Vignoli, A.(2015).TimeHistory Seismic Analysis of Masonry Building: a Comparison between Two Non-Linear Modelling Approaches.Buildings, 5(2), 597-621.

Chopra, A.K., \& Goel, R.K. (2001). A Modal Pushover Analysis Procedure for Estimating Seismic Demands for Buildings. Earthquake Engineering Structural Dynamics, 31(3), 561-582.

Guleria, A. (2014). Structural Analysis of AMultiStoreyed Building using ETABS for Different Plan Configurations.International Journal of Engineering Research \& Technology,3(5),14811485.

Housner, G.W. (1956, June).LimitDesign of Structures to Resist Earthquakes.Paper presented at the1 World Conference on Earthquake Engineering, California,USA.

Juni, P. N., Gupta, S.C., \&Patel, V.R. (2017).Nonlinear Dynamic Time History Analysis of Multistoried RCC Residential G+23 Building for Different Seismic Intensities. International Journal of Engineering Resarch \& Science, 3(3), 141-148.

Kalkan, E., \&Kunnath, S.K.(2006). Adaptive Modal Combination Procedure for Nonlinear Static Analysis of Building Structures.Journal of Structural Engineering, 132(11), 1721-1731.

Khan, W., Akthar, S., \&Hussain, A.(2014).Nonlinear Time History Analysis of Tall Structure for Seismic Load using Damper.International Journal of Scientific and Research Publication, 4(4), 1-5.

Lilhanand, K.,\&Tseng, W.S.(1988, August).Development and Application of Realistic
Earthquake Time Histories Compatible with Multiple Damping Response Spectra. Paper presented at theNinth World Conference of the Earth Engineering, Tokyo, Japan.

Lu, X., Su, N.,\& Zhou, Y. (2011). Nonlinear Time History Analysis of ASuper-Tall Building with Setbacks in Elevation.The Structural Design of Tall and Special Buildings,22(7), 593-614.

Manfredi, G. (2001).Evaluation of Seismic Energy Demand.Earthquake Engineering Structural Dynamics, 30(4), 485-499.

Nakashima, M., Saburi, K., \&Tsuji, B.(1996).Energy Input and Dissipation Behaviour of Structures with Hysteretic Dampers.Earthquake EngineeringStructural Dynamics, 25(5), 483-496.

Seo, J., Hu, J.W.,\&Davaajamts, B. (2015).Seismic Performance Evaluation of Multistory Reinforced Concrete Moment Resisting Frame Structure with Shear Walls.Sustainability, 7(1), 14287-14308.

Sukamta, D. (2016, August). Inovasi dalam Desain Struktur dan Konstruksi untuk Gedung Super Tinggi. Paper presented at the Pameran dan Seminar Himpunan Ahli Konstruksi Indonesia (HAKI), Jakarta, Indonesia.

Uang, C.M., \&Bertero, V. V. (1990).Evaluationof Seismic Energy in Structures.Earthquake Engineering and Structural Dynamics, 19(1), 7790 .

Zahrah,T.F.,\&Hall,W.J.(1984). EarthquakeEnergy Absorption in SDOF Structures.Journal ofStructural Engineering, 110(8), 1757-1772.

Zheng, N., Li,Y.,\&Pan, Y.(2011). Seismic Behavior Analysis of Low Masonry Structure With Core-TieColumns.Journal of Southwest Jiaotong University, 46(1), 24-29. 